\title{
1400 years of extreme precipitation patterns over the Mediterranean French Alps and possible forcing mechanisms
}

Bruno Wilhelm ${ }^{1}$, Fabien Arnaud ${ }^{1}$, Pierre Sabatier ${ }^{1},{\text { Christian } \text { Crouzet }^{2} \text {, Elodie Brisset }}^{3,4}$, Eric Chaumillon ${ }^{5}$, Jean-Robert Disnar ${ }^{6}$, Frederic Guiter ${ }^{3}$, Emmanuel Malet ${ }^{1}$, Jean-Louis Reyss ${ }^{7}$, Kazuyo Tachikawa $^{4}$, Edouard Bard ${ }^{4}$, Jean-Jacques Delannoy ${ }^{1}$

(1) EDYTEM, Université de Savoie - CNRS, Pôle Montagne, 73376 Le Bourget du Lac, France

(2) ISTerre, Université de Savoie - CNRS, bâtiment Belledonne, 73376 Le Bourget du Lac, France (3) IMBE, Aix-Marseille Université - CNRS, Europole de l'Arbois, BP 8013545 Aix-en-Provence cedex 04, France

(4) CEREGE, Aix-Marseille Université - CNRS, Europole de l'Arbois, BP 8013545 Aix-en-Provence cedex 04, France

(5) LIENSs, Université de La Rochelle - CNRS, Institut du Littoral et de l'Environnement, 2 rue Olympe de Gouges, 17000 La Rochelle, France

(6) ISTO, Université d'Orléans - CNRS, Campus Géosciences, bâtiment ISTE, 1A rue de la Férolerie 45071 ORLEANS cedex 2, France

(7) LSCE, Université de Versailles Saint-Quentin CEA-CNRS, avenue de la terrasse, 91198 Gif-surYvette cedex, France

e-mail : bruno.wilhelm@univ-savoie.fr

tel : $0033[0] 479758784$

fax : 0033 [0] 479758171 


\section{Abstract}

Investigation of Lake Allos sediments revealed 160 graded layers, interpreted as flood deposits, over the last 1400 yr. Comparisons with records of historic floods support the interpretation of flood deposits and suggest that most recorded flood events are the result of intense meso-scale precipitation events. As there is no evidence for any major changes in erosion processes in the catchment since the Medieval Warm Period (MWP), we interpret the Allos record in terms of repeated intense precipitation events over the last millennium, with a low flood frequency during the MWP and more frequent and more intense events during the Little Ice Age. This interpretation is consistent with the pattern of increasingly humid conditions in the northwestern Mediterranean region. This long-term trend is superimposed on high frequency oscillations that correlate with solar activity and autumnal North Atlantic Oscillation (NAO). Finally, a comparison of flood records across the northwestern Mediterranean region showed that intense precipitation events in Allos (east of the Rhône Valley) were out of phase with events in the Cévennes (west of the Rhône) but in phase with events in eastern Spain. Supported by meteorological analyses, this suggests an oscillation in atmospheric circulation patterns over the northwestern Mediterranean.

Keywords: paleoflood, flood intensity, last millennium, Mediterranean climate, solar activity, North Atlantic Oscillation

\section{Introduction}

Mountain-river floods triggered by extreme precipitation events can cause substantial human and economic losses (Gaume et al., 2009). Global warming is expected to lead to an increase in the frequency and/or intensity of such events (IPCC, 2007), especially in the Mediterranean region (Giorgi and Lionello, 2008). However, it is difficult to determine the relationship between such flood events and past climate change because the stochastic nature of extreme events precludes the identification of trends. This problem is compounded by a lack of long-term instrumental data (e.g., Beniston et al., 
2007). Consequently, reconstructions of geological records of intense events are an essential tool for extending documentary records beyond existing observational data and thereby building a better understanding of how local and regional flood hazard patterns evolve in response to changes in climate. The results of such studies can be used to improve predictive models of the consequences of global warming (Solomon et al., 2007, and references therein).

Lake sediments are continuous archives in which the identification of high-energy sediment layers can be used to reconstruct flood records (e.g., Arnaud et al., 2002; Moreno et al. 2008) and the thickness of flood deposits can, in some cases, be used as a proxy for flood intensity (Irmler et al. 2006; Nesje et al. 2001). Although, changes in vegetation and/or land-use can modify soil stability/erodibility (Lanci et al., 2001; Dapples et al., 2002) and therefore the relationship between single-event terrigenous inputs and flood intensity (Giguet-Covex et al., 2011), the size of the coarsest sediment fraction still reflects stream flow velocity (Francus et al., 2002; Beierle et al., 2002).

Analysis of a Spanish lake sediment archive allowed Moreno et al. (2008) to infer that intense precipitation events occurred more frequently during the Little Ice Age (LIA) than they did during the Medieval Warm Period (MWP). These authors also suggested that high flood frequencies were linked to both solar activity maxima and negative North Atlantic Oscillation (NAO) phases. In the northern Italian Alps, the distribution of debris-flow layers in a sequence of lake sediments deposited over the last $2000 \mathrm{yr}$ was interpreted as indicating a high frequency of extreme precipitation events during the LIA (Irmler et al., 2006). However, the climatic interpretation of debris-flow records is site-dependent and subject to debate (e.g., Jakob et al., 2005; Stoffel et al., 2011). The lack of long-term records of extreme precipitation events (Luterbacher et al., 2002; Pauling et al., 2006) is shown by the fact that the above-mentioned studies are the only reconstructions of such events over the last millennium in the northern Mediterranean region, despite the area being particularly sensitive to flood hazards (Gaume et al., 2009). The present study was designed to help redress this situation by constructing a flood record for a site in the Mediterranean French Alps for the last millennium. In order to ascertain the dominant forcing on erosion processes, we first analyzed the sedimentary sequence for signals 
indicating flood deposits and examined the pollen record to determine the area's land-use history. We then compared the record of paleoflood occurrences at Allos with local historic events and other longterm flood or climatic records. This enabled us to interpret the reconstructed flood signal and to investigate the relationship between extreme precipitation events and climate change in the northwestern Mediterranean region.

\section{Site description and setting}

Lake Allos and its tributaries

Lake Allos (2230 m a.s.1., $\left.44^{\circ} 14^{\prime} \mathrm{N}, 6^{\circ} 42^{\prime} 35 \mathrm{E}\right)$ is a 1-km-long by 700 -m-wide, high-altitude lake in the French Alps. It is located approximately $100 \mathrm{~km}$ from the Mediterranean Sea (Fig. 1) and situated in a $5-\mathrm{km}^{2}$-north-facing cirque, surrounded by sandstone mountains that rise to $2672 \mathrm{~m}$ a.s.1. Half of the catchment is drained by three permanent torrents, all of which flow into the lake (Fig. 1 and 2). The Laus torrent drains a regularly sloped sub-catchment $\left(35^{\circ}\right)$ made up of carbonate conglomerates locally covered by several meters of easily erodible glacial till. This stream has built a steep delta where it enters the lake. In contrast, the Lac torrent incises the lakeshore, indicating reduced terrigenous flows toward the lake. The Source torrent drains an area of fractured limestone and enters the lake through a large delta. Hence, the Laus and Source torrents are the dominant sources of sediment entering the lake. Detrital inputs only occur during the summer and the fall, as the catchment is covered by snow and the lake is frozen from November/December to May/June. The lake's outlet, on its northern edge, feeds the Chadoulin River, which stops flowing during exceptionally dry summers. The outlet area is covered by larch forest, whereas the catchment has only very sparse tree cover. Most of the catchment (70\%) consists of rock and scree (70\%) with alpine meadow vegetation covering most $(29 \%)$ of the remaining area.

Climate and historic floods 
The Mediterranean climate is characterized by quite dry summers and relatively wet falls (Frei and Schär, 1998, Kieffer-Weisse, 1998). Most intense precipitation events occur between June and October/November (Kieffer-Weisse and Bois, 2001), with summer events being the result of local convective phenomena (Kieffer-Weisse, 1998, Remaître, 2006) and fall events generally resulting from meso-scale convective systems that affect more extensive areas and that can trigger regional catastrophic floods (Buzzi and Foschini, 2000; Boudevillain et al., 2009). Past flood events have been documented from studies of local historical records. This data (stored in a free-to-access database managed by the National Forestry Office and the Mountain Terrain Restoration Service), shows that the village of Allos (5 km downstream from the lake) has been affected by flooding of the Chadoulin River eight times since the end of the $18^{\text {th }}$ century; in 1788, 1 November 1843,16 August 1868 , in 1886, 23 September 1920, 24 September 1994, 5 November 1994 and 19 June 2005 (see the supplementary material for details on these events).

\section{Material and methods}

Seismic survey and coring

We carried out a coupled bathymetric and seismic survey of the sediment infill, using a threetransducer CHIRP sonar (IXSEA, Echoes 5000) from the University of La Rochelle (LIENSs Laboratory) as the seismic source, combined with a short streamer mounted on a dinghy-towed fish. Chirp length was $10 \mathrm{~ms}$ and band-pass frequency was 2 to $8 \mathrm{kHz}$ (vertical resolution $\sim 20 \mathrm{~cm}$ ). Seismic data processing was carried out using Delph Seismic Software, consisting of gain correction and bandpass filtering. Two-way travel time to depth conversion was based on a P-wave velocity of $1600 \mathrm{~m} . \mathrm{s}^{-1}$ (Hamilton, 1972). Navigation was via a differential GPS system.

In order to constrain the sedimentological behavior of the lake basin, we retrieved thirteen sediment cores using an UWITEC gravity corer. The results presented here are for the three cores that were most representative of flood activity and that covered the longest period. Cores ALO09P12

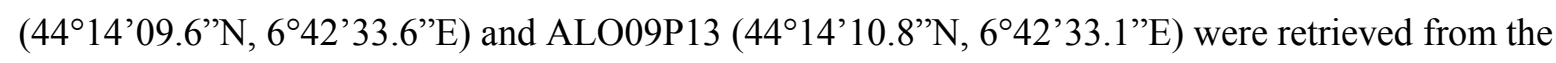


northern basin, at two different locations in front of the delta, in order to investigate changes in river

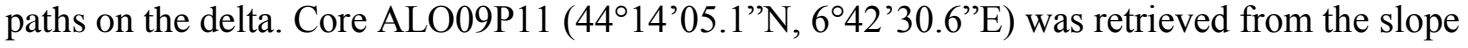
between the two basins, in a more distal position with respect to the two deltas. Sediment from this core was used for palynological analysis.

Core description and logging

The cores were split lengthwise and photographed for high-resolution $\left(20\right.$ pixels.mm $\left.{ }^{-1}\right)$ visual analysis of lithologies and sedimentary facies.

We carried out grain size analyses on core ALO09P13 (Malvern Mastersizer S), sampling at a continuous interval of $5 \mathrm{~mm}$. We then used the median (Q50) and coarsest fractions (Q90) to characterize interbedded deposits (Passega, 1964; Mulder et al., 2001).

Geochemical analyses were carried out on the CEREGE laboratory's Itrax ${ }^{\mathrm{TM}}$ (Cox Analytical Systems) X-ray fluorescence (XRF) core scanner, using a chromium tube (35 keV, $45 \mathrm{~mA}$ ) with a 15-s count-time and a 1-mm sampling step. The areas of the element peaks obtained are proportional to the concentrations of each element (Tachikawa et al., 2011). We quantified total organic carbon contents (TOC) for cores ALO09P11 (1-cm sampling step) and ALO09P12 (2-cm sampling step) using a “Turbo" model RE6 pyrolyzer at the ISTO laboratory (see Lafargue et al., 1998, for procedure details).

Pollen analysis

Pollen analyses were carried out at the IMBE laboratory. We chose core ALO09P11 for these analyses, as its distal position with respect to the stream inlets was more favorable to the preservation of pollen grains and spores. Constant volume $(4 \mathrm{ml})$ pollen samples were taken and processed using the method described by Faegri and Iversen (1989). For each sample, we counted at least 300 terrestrial-vascular plantpollen grains, which we identified under the microscope at 500× magnification under oil immersion. We identified and counted 78 taxa but our summary pollen diagram, drawn using 
C2 software (Juggins, 2007), only shows selected taxa. We calculated the pollen frequency for each taxon as a percentage of the total pollen. For ecological reasons, we excluded spores from the pollen totals. We obtained the pollen curve for Quercetum mixtum (mixed oak forest) by aggregating percentages for the deciduous genera Quercus, Tilia, Acer, Ulmus and Fraxinus. The Abies/Fagus (beech/fir grove) curve shows total percentages for Abies and Fagus, and the Mediterranean trees curve shows total percentages for Pistacia and Quercus ilex. The "local anthropogenic taxa" curve summarizes the dynamics of flora associated with local human activities, that is, ruderal and nitrophilous herbs such as Galium, Rumex, Urtica, Mentha, Plantago lanceolata and Plantago coronopus.

Dating methods

We measured short-lived radionuclides $\left({ }^{210} \mathrm{~Pb},{ }^{137} \mathrm{Cs}\right.$ and $\left.{ }^{241} \mathrm{Am}\right)$ in the uppermost $16 \mathrm{~cm}$ of core ALO09P12, following a non-regular sampling step of 0.5 to $1 \mathrm{~cm}$, in order to match facies boundaries, and using 1-3 g samples of dried sediment. Measurements were made by gamma spectrometry, using high-efficiency, very low background, well-type Ge detectors in the Modane underground laboratory (Reyss et al. 1995). Generally, counting times of 24 to $48 \mathrm{hr}$ were required to reach a statistical error of less than $10 \%$ for excess ${ }^{210} \mathrm{~Pb}$ in the deepest samples and for the $1963{ }^{137} \mathrm{Cs}$ and ${ }^{241} \mathrm{Am}$ peaks. Excess ${ }^{210} \mathrm{~Pb}$ was calculated as the difference between total ${ }^{210} \mathrm{~Pb}$ and ${ }^{226} \mathrm{Ra}$ activities. We then used the Constant Flux/Constant Sedimentation (CFCS) model and the decrease in excess ${ }^{210} \mathrm{~Pb}$ to calculate the sedimentation rate (Goldberg, 1963). The uncertainty of the sedimentation rate obtained by this method was derived from the standard error of the linear regression of the CFCS model.

In order to obtain additional chronological markers, we compared the natural remnant magnetization (NRM) versus depth with known secular variations in the geomagnetic field (Barletta et al., 2010). Paleomagnetic investigations were performed on u-channel sub-samples of core ALO09P12, using a 3-axis, 2-G enterprise cryogenic magnetometer at the CEREGE laboratory. Because the magnetometer has three orthogonal coils it was possible to use the alternating field demagnetization procedure. Each 
sample's NRM was progressively demagnetized using (AF) in 10, 20, 30, 40 and $60 \mathrm{mT}$ steps. The demagnetization diagrams (Zijderveld, 1967) showed that behavior was mainly unidirectional. In the small number of cases with two overlapping components, the softer component was removed above 30 mT AF. Thus, we used the characteristic remnant magnetization (ChRM) obtained after demagnetization of the $\mathrm{NRM}_{40 \mathrm{mT}}$ for directional analyses. Samples affected by side effects were removed. We also imparted and demagnetized the samples' isothermal and an hysteretic remnant magnetization in order to ensure there is no change in magnetic mineralogy. Because the magnetic carrier properties were very stable all along the studied section, we could be confident in the resulting NRM direction.

Small-size vegetal macro-remains were sampled at the base of flood deposits. Identifiable pine needles, buds, twigs and leaves were separated and sent for AMS ${ }^{14} \mathrm{C}$ analysis at France's LMC14 carbon-dating laboratory. ${ }^{14} \mathrm{C}$ ages were calibrated (Intcal09 calibration curve, Reimer et al., 2009; Table 1) and an age-model generated using the R-code package "clam" (Blaauw, 2010).

Core ALO09P12 was dated using all the above dating methods, whereas core ALO09P13 was dated via the fine stratigraphic correlation of 156 thick, graded beds, and distal core, ALO09P11, was dated via synchronous geochemical variations.

\section{Results and interpretations}

Lake morphology and sediment infill

The lake basin consists of a shallow platform (20 m deep) to the north and a deep basin (42 $\mathrm{m}$ deep) to the south (Fig. 1). Seismic data shows the sediment sequence to be well stratified with no evidence of major mass-wasting deposits. The morphology of the acoustic substratum, interpreted as bedrock, indicates flat areas correspond to two distinct sub-basins. Cores ALO09P12 and ALO09P13 were 
retrieved from the depocenter of the shallow basin, whereas core ALO09P11 was taken on the slope separating the two sub-basins.

Sedimentology

The sediment sequence consists of beds of homogeneous silty clay alternating with coarser, normally graded beds (Figs. 3 and 4). All the cores contained two horizons that were greatly enriched in organic carbon and sulfur (Fig. 3). Stratigraphical correlations between the cores based on these horizons showed that ALO09P11 contains the most condensed sediment sequence. Analyses of the interbedded normally graded beds showed a sharp and coarse base overlain by a well-developed fining-upward basal unit and a thin, whitish, fine-grained uppermost unit (Fig. 4). These beds had higher dry bulk densities, lower TOC values and higher calcium contents than the silty clay beds. In addition, the bases of the normally graded beds contained macro-remains of terrestrial vegetation. Normally graded beds are common features of lake sediments, where they are associated with turbidity currents triggered by gravity reworking or flood events (Sturm and Matter, 1978; Arnaud et al., 2002; Gilbert et al., 2006). Because the Lake Allos sequence consists of 160 normally graded beds in less than $2 \mathrm{~m}$ of sediment, and because these beds all contained markers indicating an allochtonous origin for the sediment (terrestrial macro-remains and Ca-enrichment), we interpreted them as flood deposits rather than gravity-reworking deposits (e.g., Sturm and Matter, 1978; Gilbert et al., 2006). In addition, 156 of the normally graded beds correlated well between cores ALO09P12 and ALO09P13, but six thin graded beds occurred only in core ALO09P13 (Fig. 3). This suggests that changes in river paths on the delta during flood events occurred very rarely (4\% of floods) and that the two cores are representative of the flood activity. Figure 4 compares the thickness and the $\mathrm{Q}_{90 \max }$ (i.e., the highest $\mathrm{Q}_{90}$ value of each graded bed) of the 53 beds thicker than $4 \mathrm{~mm}$ in core ALO09P13. This comparison could only be done for beds thicker than $4 \mathrm{~mm}$ because of the 5 -mm sampling step used for grain size measurements. In the present case, the significant positive linear relationship between bed thickness and $\mathrm{Q}_{90 \max }(\mathrm{r}=0.88$, $\mathrm{n}=53, p<10^{-4}$ ) allowed us to use bed thickness as a high-resolution proxy for stream velocity during 
flood events (Molinaroli et al., 2009, Parris et al., 2010) and therefore as a proxy for flood intensity (e.g., Bøe et al., 2006; Schiefer et al., 2011).

Chronology

\section{Short-lived radionuclides}

The excess ${ }^{210} \mathrm{~Pb}$ profile for core ALO09P12 showed a regular decrease down to a very low value $(<15 \mathrm{~Bq} / \mathrm{kg})$, punctuated by sharp dips to low values for three layers $(2.1-3.3 \mathrm{~cm}, 10.2-11.3 \mathrm{~cm}$ and 13.2-14.9 cm) of thick, graded deposits (Fig. 5A). In line with Arnaud et al. (2002), we excluded ${ }^{210} \mathrm{~Pb}$ values associated with instantaneous deposits in order to construct a synthetic sedimentary record (Fig. 5B). Plotting the resulting excess ${ }^{210} \mathrm{~Pb}$ profile on a logarithmic scale revealed two distinct point alignments. Applying the CFCS model (Goldberg, 1963) gave mean accumulation rates of 1.12 $\pm 0.1 \mathrm{~mm} \cdot \mathrm{yr}^{-1}$ for the top $8 \mathrm{~cm}$ of the core and $0.8 \pm 0.1 \mathrm{~mm} \cdot \mathrm{yr}^{-1}$ for the lower section of the core. Ages derived using the CFCS mode were applied to the original sediment sequence to give a continuous age-depth relationship (Fig. 5C). In addition, the profiles contained peaks for ${ }^{241} \mathrm{Am}$ and ${ }^{137} \mathrm{Cs}$ (Fig. 5A). The ${ }^{241} \mathrm{Am}$ peak, between 5.1 and $6.1 \mathrm{~cm}$, is characteristic of the decay of ${ }^{241} \mathrm{Pu}$ in fallout from atmospheric nuclear weapons tests(Appleby et al., 1991); hence, the maximum ${ }^{241}$ Am value can be taken to correspond to the end of nuclear weapon tests in the northern hemisphere, in 1963 . The ${ }^{137} \mathrm{Cs}$ peak can be attributed to fallout from the Chernobyl accident in 1986. The agreement between these independent chronological markers and the ${ }^{210} \mathrm{~Pb}$ ages strongly support our age-depth model for the last century (Fig. 5C).

Age-depth model based on variations in the geomagnetic field and ${ }^{14} \mathrm{C}$ ages

We used measured and reconstructed declination variations over the last millennium (compilation from Bucur, 1994; Alexandrescu et al., 1997; Gallet et al, 2002) to identify magnetic declination minima and maxima. These occurred in $\mathrm{AD} 1805 \pm 15,1530 \pm 65,1360 \pm 15$ and $950 \pm 40$ (D-1 to D-4, respectively, Fig. 6A). The ChRM declination profile of core ALO09P12 also showed four declination features during this period, at depths of $37 \pm 1,56,82$ and $108 \mathrm{~cm}$, allowing the 
correlation with the reconstructed declination variations (Fig. 6A). These well-correlated declination features provided additional chronological markers that we combined with the short-lived radionuclides results and the ${ }^{14} \mathrm{C}$ ages (Table 1) to construct an age-depth model. As noted above, we removed flood layers in order to construct a synthetic sedimentary record (Bøe et al., 2006, GiguetCovex et al., 2011). We then calculated an age-depth relationship using a smoothing spline and the “clam" R-code package (Blaauw, 2010; Fig. 6B). We obtained reliable dates for the graded beds in core ALO09P13 based on the correlation of these beds with those in the dated-core ALO09P12 by using the visual lithological descriptions and the Ca signal (Fig. 3). This allowed us to build a record of Laus torrent floods over the last 1400 yr. For each graded bed, the thickness was attributed to the age (Fig. 8), and we calculated the mean thickness of corresponding flood deposit beds in cores ALO09P12 and ALO09P13, in order to take into account possible changes of river paths. Finally, we determined the age-depth relationship for core ALO09P11 by correlating the two organic-rich, silty clay layers.

Vegetation dynamics

The pollen record is dominated by Pinus type sylvestris (Fig. 7). Pinus pollen is generally overrepresented in pollen records from high-mountain areas because it is widely and massively disseminated by the wind (Couteaux, 1991), particularly in open landscapes dominated by grassland. Consequently, high Pinus pollen values cannot be interpreted as indicating the presence of pine forests close to the lake. These pollen values are more probably due to the presence of scattered stands of pine trees in the upper parts of the valley. The base of core ALO09P11 (Local Pollen Assemblage Zone (LPAZ) 1; Fig. 7) is characterized by the presence of Juglans, low Quercetum mixtum pollen concentrations, a major peak for Poaceae and continuous occurrences of "local anthropogenic taxa". LPAZ 2 is characterized by the first occurrences of pollen from Mediterranean trees, a major peak for arboreal pollen and a continuous curve of Artemisia. There are no Mediterranean trees in the immediate vicinity of the lake, but the substantial quantities of Mediterranean tree pollen in these samples indicate that the landscape surrounding the lake was open. The subsequent zone, LPAZ 3, is 
characterized by a general decrease in tree pollen (decreasing AP/NAP curve) and high levels of wild grass pollen, such as Poaceae, Cerealia and Ericaceae. This may indicate a significant local and regional destabilization of the mountain ecosystem due to agro-pastoral activities. During LPAZ 4, an increase in the amount of Olea and Juglans pollen is accompanied by a decrease in Quercetum mixtum pollen. This zone also includes a second Poaceae peak, suggesting a continuation of the preceding major disruption in forest dynamics. The most recent zone, LPAZ 5, is characterized by a reduction in non-arboreal pollen and a simultaneous increase in Pinus pollen, as well as the appearance of macroremains of gymnosperms (sub-fossil xylem tracheids). The increase in Pinus pollen and the appearance of gymnosperm macro-remains suggest a recent and progressive recolonization of pine trees from the lower valley to the lake. This is consistent with the current landscape. Overall, the pollen record suggests that the landscape around the lake has been mostly open since LPAZ2, and that agro-pastoral activities occurred throughout the valley during the entire study period.

\section{Discussion}

The Lake Allos flood record and its representativeness as a regional climate proxy

Once a flood record has been established from proxies, the representativeness of that record has to be determined. Graded beds are generally interpreted as being formed by increases in river discharge, with the high energy features of these beds suggesting that they are the result of flood events, rather than snow melt (e.g., Enters et al., 2010; Giguet-Covex et al., 2012; Wilhelm et al., in press). In the case of Lake Allos, historical sources can be used to determine whether the record merely reflects flooding caused by local meteorological events or whether it can be used as a regional climate proxy. In addition, it is necessary to assess the effect of land-use changes on erosion patterns, which can be done using pollen data.

\section{The historically well-documented period: local to regional comparison}

In order to assess the local reliability of the Allos flood reconstruction, we used the ${ }^{210} \mathrm{~Pb}$ based ages to determine whether or not the uppermost thick graded beds correlate with documented 
floods of the Chadoulin River. The most recent graded bed, which only occurred in core ALO09P13, was dated to AD $2005 \pm 1$ (Fig. 3), suggesting that it corresponds to a local but violent storm that occurred in June 2005. Downcore, the two thick deposits were dated to AD $1995 \pm 2$ and $1994 \pm 2$, respectively (Fig. 5C). Both dates and the sediments between these deposits provide a good match with two catastrophic flood events that occurred in September and November 1994. Thick flood deposits lower in the cores were dated to $\mathrm{AD} 1915 \pm 5$ and $1881 \pm 7$, and may correspond to deposits formed by the floods of 1920 and 1886. Other thick flood deposits occurred below the range of the ${ }^{210} \mathrm{~Pb}$ dating method, suggesting that they were formed in the second part of the $19^{\text {th }}$ century. The dates of $\mathrm{AD} 1862 \pm 9$ and $1851 \pm 10$ obtained for these deposits by extrapolating the mean sedimentation rate of $0.8 \mathrm{~mm} . \mathrm{yr}^{-1}$ are consistent with their formation by the historical floods of August 1868 and 1843 . However, the absence of evidence supporting the assumption of a continuous sedimentation rate below the range of the ${ }^{210} \mathrm{~Pb}$ dating method makes these correlations uncertain. Although there are records of an older flood, in 1788, it would be hazardous to try and correlate this event with a sediment horizon due to the absence of independent chronological controls and the presence of numerous graded beds. Overall, the good agreement between major historical floods in the last $150 \mathrm{yr}$ and the calculated ages of the thick graded beds supports the interpretation that these beds were deposited by intense flood events. However, some events (e.g., the June 2005 and November 1994 floods) occurred close to times of the year when the lake is usually covered by ice, suggesting that there is a possibility that a flood event may occur when the lake is still ice bound and therefore not be recorded.

To investigate whether or not the Allos flood record is representative of flood events across the region, we compared it with recorded floods for the River Ubaye, approximately $15 \mathrm{~km}$ north of Lake Allos, and its main tributaries (Fig. 1), covering periods of 400 and $150 \mathrm{yr}$, respectively (Remaitre, 2006; Sivan et al., 2009, Fig. 8). This comparison showed that periods of high flood-frequency for the River Ubaye were concomitant with those for its tributaries and at Allos (Figs. 8B). This concordance in flood timing over a range of catchment sizes (from 0.5 to $1000 \mathrm{~km}^{2}$ ) suggests that most major floods are caused by meso-scale intense precipitation events. In areas with a Mediterranean climate, such 
meso-scale events most commonly occur in the fall. In contrast, the extreme precipitation rates and torrential floods associated with summer thunderstorms tend to be highly localized (e.g., Merz and Blöschl, 2003; Sivan et al., 2009; Wilhelm et al., in press). These observations led us to interpret the Allos flood record as a signal dominated by regional events. Moreover, the good agreement between different flood records during a cold phase of the LIA (Guiot et al., 2010; Corona et al., 2011) also suggests that the Allos flood signais are reliable, even if some events are missed during winters when the lake is covered in ice for longer than usual.

\section{The last millennium: potential influence of land-use changes}

The climatic information provided by our reconstruction of the Allos flood record for the last few centuries can be considered relevant to longer periods if there have not been any major changes in erosion processes. Changes in erosion processes in high-altitude regions can result from changes in land use and/or soil freeze/thaw due to the presence/absence of permafrost. However, the aspect (west) and altitude (up to $c a .2350 \mathrm{~m}$ a.s.l.) of the area eroded by the Laus tributary suggest that the area was unlikely to have been affected by permafrost (e.g., Haeberli, 1975; Stoffel et al., 2005). In addition, an effect of permafrost on erosion processes is incompatible with the high frequency of flood layer formation during the LIA, and the fact that this period also saw the formation of the thickest flood layers. Consequently, our analysis focused uniquely on land use changes. The first period of high flood frequency, around AD 700-800 (Fig. 8), was contemporaneous with major anthropogenic disturbance and with the greatest changes in vegetation dynamics during the study period (Fig. 7). Hence, the peak in flood frequency may be a result of this change in land use (e.g., Dapples et al., 2002). Pollen data suggest that human impact on the environment was greatest during the MWP (LPAZ3, Fig. 7), whereas the lowest flood frequency occurred during this period, with only one peak around $\mathrm{AD}$ 1140. In contrast, during the LIA there was a general increase in stream activity, albeit with sharp variations. In addition, pollen analyses show that the percentages of anthropogenic taxa and cultivated trees remained almost constant during this period. Except for the period around AD 700, we did not find any correlation between local human activities and the flood signal during the last 1400 yr. Furthermore, the relationship between $Q_{90 \max }$ and flood-deposit thickness (Fig. 4) suggests that the 
amount of eroded material mainly depended on river flow velocity, rather than on the availability of erodible sediment. When soils are destabilized by pastoral land use, the amount of eroded material may become independent of the $\mathrm{Q}_{90}$ and a secondary pattern would be expected to appear (GiguetCovex et al., 2011). Hence, except during the $8^{\text {th }}$ century, when land-use changes destabilized the geosystem, the Allos flood record appears to have been mostly driven by climate forcing.

Variations in Allos flood activity and climate change in the northwestern Mediterranean region

\section{Multi-centennial scale}

Multi-centennial climate variations during the last millennium can be summarized as an oscillation between "warm and dry" periods and "cold and wet" periods. Three periods of different duration can be recognized; known as the Medieval Warm Period (MWP), the Little Ice Age (LIA) and the recent warm period. The MWP (AD 800-1300) was characterized by high summer temperatures in southern Europe (Guiot et al., 2010), with the exception of a short, cooler and wetter period around AD 1100 (Corona et al., 2011). Reconstructions of lake levels in southern Europe indicate that the MWP included two warmer and much dryer periods, from AD 800 to 1000 and from AD 1150 to 1300 (Morellón et al., 2009, 2011, Fig. 8C). In addition, the MWP was marked by very low hydrological activity in large rivers such as the Rhône (Arnaud et al., 2005; Debret et al., 2010), Moyenne Durance (Miramont et al., 1998) and Tagus (Benito et al., 2003), and in mountain streams such as the Taravilla lake inlet (Moreno et al., 2008). The Allos flood record is consistent with this general dry pattern, although the sharp increase in flood frequency circa AD 1150 appears anomalous, as this was a warm, dry period. However, given the uncertainty of our age model at this depth (i.e., an age error of $50 \mathrm{yr}$ over the last $1000 \mathrm{yr}$ ), this increase in flood frequency may correspond to the cold, wet phase circa AD 1100.

The onset of the LIA ( $c a$. AD 1300) was marked by a progressive shift toward cooler and wetter conditions (Guiot et al., 2010; Corona et al., 2011; Morellón et al., 2009, 2011, Fig. 8). Research has shown higher flood activity in large rivers in southern Europe, notably in France (Miramont et al., 
1998; Arnaud et al., 2005; Debret et al., 2010), Italy (Belotti et al., 2004; Giraudi, 2005) and Spain (Benito et al., 2003), and in smaller catchments (e.g., in Spain, Moreno et al., 2008). At Allos, the higher flood frequency during the LIA was accompanied by a substantial increase in deposit thickness, which we interpret as being due to an increase in the intensity of extreme rainfall events compared with the MWP (Fig. 8). Thus, the northwestern Mediterranean region was characterized by lower temperatures and wetter conditions, and by more frequent and more intense flood events in the MWP than in the LIA. This pattern is shown by sedimentary records from both Allos and Taravilla. The increased frequency of flood events is consistent with the increased flood activity of large rivers in the northwestern Mediterranean region.

\section{Sub-centennial scale}

Although there was an overall multi-centennial increase in the frequency of floods at Allos during the LIA, flood frequencies were highly variable on a sub-centennial timescale. This type of short-term variation has been recognized in a small number of paleohydrological records in the northwestern Mediterranean region. In addition, extensive research using historical documents allowed us to compare the sub-centennial variability in our signal with a detailed flood reconstruction of the Barcelona area (Barrera et al., 2006), as well as a summary of nine flood reconstructions of various rivers along Spain's Mediterranean coast (Barriendos-Vallve and Martin-Wide, 1998, Fig. 8A). First, the timings of periods of high flood frequencies shown by Spanish records, for all sizes of catchment area, are similar to those shown by records for the River Ubaye and its tributaries. In addition, there is good agreement between the flood chronologies for northeast Spain and the southern Alps (i.e., Allos and Ubaye) over the last four centuries, as high flood frequency periods (in the early $17^{\text {th }}$ century, $1750-1900$ and during the late $20^{\text {th }}$ century) and low flood frequency periods (well-marked around 1700 and in the early $20^{\text {th }}$ century) are almost synchronous. However, the concordance between flood reconstructions is weaker prior to $\mathrm{AD} 1600$. This change may be due to the intrinsic limits of the reconstructions. For example, the reconstructions for Barcelona drawn up by Barrera et al.(2006) using historical documents did not reveala consistent flood frequency trend during the first $200 \mathrm{yr}$. This may be linked to a lack of written sources for this period (Barrera et al., 2006). This interpretation is 
supported by the fact that the Lake Taravilla reconstruction indicates two high-flood frequency periods between AD 1400 and 1550 that do not occur in other reconstructions, whereas both Spanish reconstructions present strong similarities since AD 1600. Furthermore, uncertainties in the ${ }^{14} \mathrm{C}$ dates may affect the overall accuracy of the Taravilla and Allos lake sediment reconstructions.

However, the most intense precipitation events in the northwestern Mediterranean region occur in the Cévennes-Vivarais area (southern France), 250-km west of Allos. Known as "Cévenole" events, these episodes are associated with precipitation rates of up to $500 \mathrm{~mm} /$ day and are capable of triggering regional high-intensity floods. This type of meso-scale intense precipitation event is a typical feature of Mediterranean climates during the fall (Boudevillain et al., 2009; Gaume et al., 2009). Blanchemanche (2009) used historical documents to draw up a record of autumnal floods for the Rivers Vidourle and Hérault, which are affected by Cévenole events. On comparing this record with our Allos flood reconstruction, we found an inverse correlation between the periods of high flood frequency, measured on a decennial to centennial scale, in the two areas (Fig. 8). This suggests that floods in the southern Alps (i.e., Allos and Ubaye) and the Cévennes-Vivarais region are caused by different meso-scale events. Furthermore, these comparisons showed that flood frequencies were higher in the southern Alps and on Spain's Mediterranean coast than they were in the CévennesVivarais area during the periods AD 1600-1660, 1750-1900 and 1950-2000, and higher in the Cévennes-Vivarais area than in the southern Alps and on the Spanish Mediterranean coast during the periods AD 1680-1750 and 1900-1950.

Possible climate mechanisms governing the frequency of torrential floods in the northwestern Mediterranean region

Major multi-centennial changes in general precipitation patterns during cooling phases, such as the LIA, associated with long periods of reduced solar activity (Delaygue and Bard, 2011) have been recorded in western (Magny et al., 2003) and northern Europe (Bakke et al., 2008). According to Magny et al. (2003), increased moisture over western Europe during cooler periods may result from a 
southward shift and an intensification of the prevailing westerly winds, due to an increase in the thermal gradient between high and low latitudes. Simulations of mid-latitude cyclonic activity and the resulting precipitation patterns provide support for such mechanisms (Trigo and Davies, 2000; Bengtsson and Hodges, 2006; Raible et al., 2007). On the other hand, the general increase in hydrological activity at the beginning of the LIA was accompanied by a sub-centennial variability in flood frequency. Most periods of high flood frequency occurred during periods of high solar irradiance (Delaygue and Bard, 2011; Fig. 8), and a relationship between solar maxima and high flood activity has been suggested from flood reconstructions for the River Tagus (Vacquero, 2004) and the Lake Taravilla inlet (Moreno et al., 2008). According to Kirov and Georgieva (2002), secular solar activity and the NAO are linked: if secular solar activity increases, the "smoothed" NAO index decreases, and vice versa. In addition, negative NAO phases are associated with increased precipitation in southern Europe (e.g., Hurrel 1995; Sanchez-Gomez et al., 2008). Luterbacher et al. (2002) reported good agreement between periods of high flood frequency and the reconstructed fall NAO index for the last three centuries, with periods of high flood frequency at around AD 1790 and 1880 being associated with highly negative NAO values. However, few floods occurred during the negative NAO period around $\mathrm{AD} 1680$, corresponding to the Maunder solar minimum, although this period has been described as wet (e.g., Pauling et al., 2006). However, the absence of a marked increase in flood frequency has already been noted in the northwestern Mediterranean region (Barriendos, 1997). Changes in atmospheric conditions on an multi-annual time scale can also be triggered by major volcanic eruptions, which can cause negative temperature anomalies (e.g., Crowley et al., 2008), and either positive (e.g., Blass et al., 2008) or negative (Peng et al., 2010) precipitation anomalies. Comparisons between the paleo-volcanic record (Crowley et al., 2008) and the Allos record suggest that some flood events may be related to major volcanic activity. However, a consistent correlation supporting volcanism as a main trigger of intense flood event did not appear.

Finally, over the last four centuries there has been a large degree of concordance in the timing of floods in the southern Alps and on Spain's Mediterranean coast. Conversely, there is an inverse relation between flood frequencies in these two regions and those in the Cévennes-Vivarais region. 
The meteorological and atmospheric-circulation patterns that led to intense precipitation events in the southern Alps and the Cévennes-Vivarais region between 1994 and 2006 have been closely analyzed (Buzzi and Foschini, 2000; Jansa et al., 2000; Ducrocq et al., 2008; Boudevillain et al., 2009; Fig. 9). The results for both areas show that, in the fall, intense precipitation is linked to the still warm Mediterranean Sea moistening and warming the lower atmosphere. During periods of southerly airflow, unstable air masses are carried toward the coast where convection develops, often triggered by the air flowing over the cooler land and being pushed to higher altitudes by the relief. However, on a meso-scale, the direction of the prevailing winds in the lower layers of the atmosphere will depend on the position of the depression center (Boudevillain et al., 2009). Meteorological analyses show that Cévenole events occur when the winds blow from the south or southeast, whereas extreme precipitation events in the southern Alps and the Gulf of Genoa occur when the winds are from the southwest (Boudevillain et al., 2009; Fig. 9). These differences might explain the differences in the reconstructed flood patterns for these two regions. Moreover, the fact that southern Alps-type flood events occur during periods of southwesterly airflow, that is, when the airflow comes from the eastern coast of Spain, suggests that the same meso-scale intense precipitation event might trigger flood events over both eastern Spain and the southern Alps. Combining this observation with reconstructed flood patterns may suggest a 50 to 150-yr oscillation between the two northwestern Mediterranean atmospheric circulation paths that result in intense precipitation events in the area, and that this oscillation has occurred for at least the last $400 \mathrm{yr}$.

\section{Conclusion}

A multi-proxy investigation of the Lake Allos sediment sequence revealed 160 interbedded layers formed over the last $1400 \mathrm{yr}$. These layers are characterized by a sharp and coarse base, a finingupward trend, high density, low TOC values, the presence of terrestrial vegetal remains and systematic $\mathrm{Ca}$ enrichment. The characteristics and frequent occurrence of these deposits suggest that they were formed by high-energy sediment inputs during mountain-torrent floods resulting from extreme precipitation events. In addition, the relationship between the thickness of the graded beds and their 
basal grain size led us to use bed thickness as a proxy for flood intensity. Comparisons with reconstructions of local historical floods over the last $400 \mathrm{yr}$ suggest that most of these floods were triggered by autumnal, meso-scale intense precipitation events. As there is no evidence for major changes in erosion processes linked to human activities since the MWP, the Lake Allos sediment sequence can be regarded as a record of floods caused by intense precipitation events during the last millennium.

On a multi-centennial time scale, the frequency of Allos flood events is consistent with the general moisture, large-river hydrology and temperature patterns in the northwestern Mediterranean region, that is, low flood activity during the warm/dry MWP and high flood activity during the cold/wet LIA. Although there was a general increase in flood frequency during the multi-centennial period of the LIA, on a sub-centennial scale flood frequencies were highly variable. This variability may be in phase with solar maxima. In addition, flood frequency peaks appear to be related to autumnal negative NAO phases. Such a relationship has already been reported following paleoflood reconstructions for Spanish rivers (Benito et al., 2003; Moreno et al., 2008). Finally, comparing flood-frequency patterns for different northwestern Mediterranean sites may suggest a 50 to 150-yr oscillation between the two northwestern Mediterranean atmospheric circulation paths that result in intense precipitation events in this region.

Overall, our study shows that sediment sequences from high altitude lakes can provide reliable records of flood - frequency and intensity - patterns related to extreme precipitation events. This opens up the possibility of using such records to investigate the evolution of extreme weather events during longterm periods of climate change. Such information is required to determine the possible impact of the current phase of global warming and therefore better anticipate its impact on societies.

\section{Acknowledgments}


B. Wilhelm's PhD fellowship was supported by a grant from the Assemblée des Pays de Savoie and the Communauté de Communes du Grésivaudan. Logistical and financial support was provided by the French National Research Agency's Pygmalion project (ANR BLAN07-2_204489). Radiocarbon dating was performed by the national facility LM14C laboratory as part of an INSU ARTEMIS grant proposal. The authors thank Claire Dehlon for her help in identifying vegetal remains, François Demory for his helpful discussions and for providing access to the CEREGE's paleomagnetism laboratory, Jean-Pascal Dumoulin for his careful processing of our samples for radiocarbon dating, Marta Garcia for her excellent technical advices on using the core scanner, Paul Henderson for the improvement of English, Yoan Laurent for his assistance in processing the seismic data, Marie Revel for her help in the fieldwork and the Mountain Terrain Restoration department of the National Forestry Service for allowing access to its database of historic floods. We also thank Cécile Miramont, an anonymous reviewer, Lothar Schulte and the editors for their constructive comments that greatly improved this manuscript.

\section{References}

Alexandrescu, M., Courtillot, V., Le Mouël, J.-L., 1997. High-resolution secular variation of the geomagnetic field in western Europe over the last 4 centuries : comparison and integration of historical data from Paris and London. Journal of Geophysical Research 102, 20245-20258.

Appleby, P.G., Richardson, N., Nolan, P.J., 1991. ${ }^{241}$ Am dating of lake sediments. Hydrobiologia 214, $35-42$.

Arnaud, F., Lignier, V., Revel, M., Desmet, M., Pourchet, M., Beck, C., Charlet, F., Trentesaux, A., Tribovillard, N., 2002. Flood and earthquake disturbance of ${ }^{210} \mathrm{~Pb}$ geochronology (Lake Anterne, North French Alps). Terra Nova 14, 225-232. 
Arnaud, F., Revel, M., Chapron, E., Desmet, M., Tribovillard, N., 2005. 7200 years of Rhône river flooding activity in Lake Le Bourget, France: a high-resolution sediment record of NW Alps hydrology. The Holocene 15(3), 420-428.

Bakke, J., Lie, Ø., Dahl, S.O., Nesje, A., Bjune, A.E., 2008. Strength and spatial patterns of the Holocene wintertime westerlies in the NE Atlantic region. Global and Planetary Change 60, 28-41.

Barriendos Vallve, M., Martin-Wide, J., 1998. Secular climatic oscillations as indicated by catastrophic floods in the Spanish Mediterranean coastal area (14th-19th centuries). Climatic Change $38,473-491$.

Barletta, F., St-Onge, G., Channell, J.E.T., Rochon, A., 2010. Dating of Holocene western Canadian Arctic sediments by matching paleomagnetic secular variation to a geomagnetic field model. Quaternary Science Reviews 29, 2315-2324.

Barrera, A, Llast, M.C., Barriendos, M., 2006. Estimation of extreme flash flood evolution in Barcelona County from 1351 to 2005. Natural Hazards Earth Systems Sciences 6, 505-518.

Barriendos, M., 1997. Climatic variations in the Iberian Peninsula during the late Maunder Minimum (AD 1675-1715): an analysis of data from rogation ceremonies. The Holocene 7, 105-111.

Beierle, B.D., Lamoureux, S.F., Cockburn, J.M.H., Spooner, I., 2002. A new method for visualizing sediment particle size distributions. Journal of paleolimnology 27, 279-283.

Belotti, P., Caputo, C., Davoli, L., Evangelista, S., Garzanti, E., Pugliese, F., Valeri, P., 2004. Morpho-sedimentary characteristics and Holocene evolution of the emergent part of the Ombrone River delta (southern Tuscany). Geomorphology 61, 71-90. 
Beniston, M., Stephenson, D.B., Christensen, O.B., Ferro, C.A.T., Frei, C., Goyette, S., Halsnaes, K., Holt, T., Jylhä, K., Koffi, B., Palutlikof, J., Schöll, R., Semmler, T., Woth, K., 2007. Future extreme events in European climate: an exploration of regional climate model projections. Climatic Change 81, $71-95$.

Benito, G., Díez-Herrero, A., Fernández de Villalta, M., 2003. Magnitude and frequency of flooding in the Tagus Basin (Central Spain) over the last millennium. Climatic Change 58, 171-192.

Bengtsson, L., Hodges, K.I., 2006. Storm Tracks and Climate Change. Journal of Climate 19, 35183543.

Blaauw, M., 2010. Methods and code for 'classical' age-modelling of radiocarbon sequences. Quaternary Geochronology 5, 512-518.

Blanchemanche, P., 2009. Crues historiques et vendanges en Languedoc méditerranéen oriental : la source, le signal et l'interprétation. In : Changement global, effets locaux : Le Petit Age Glaciaire dans le Sud de la France : Impacts morphogéniques et sociétaux. Archéologie du Midi Médiéval 27, 225235.

Blass, A., Grosjean, M., Livingstone, D.M., Sturm M., 2008. Signature of explosive volcanic eruptions in the sediments of a high-altitude Swiss lake. Journal of Paleolimnology 39, 35-42.

Bøe, A.G., Olaf Dahl, S., Lie, O., Nesje, A., 2006. Holocene river floods in the upper Glomma catchment, southern Norway: a high-resolution multiproxy record from lacustrine sediments. The Holocene 16(3), 445-455.

Boudevillain, B., Argence, S., Claud, C., Ducrocq, V., Joly, B., Lambert, D., Nuissier, O., Plu, M., Ricard, D., Arbogast, P., Berne, A., Chaboureau, J.P., Chapon, B., Crépin, F., Delrieu, G., Doerflinger, 
E., Funatsu, B.M., Kirstetter, P.E., Masson, F., Maynard, K., Richard, E., Sanchez, E., Terray, L., Walfpersdorf, A., 2009. Cyclogenèses et précipitations intenses en région méditerranéenne:origines et caractéristiques. La Météorologie 66, 18-28.

Bucur, I., 1994. The direction of the terrestrial magnetic field in France during the last 21 centuries. Physics of the Earth and Planetary Interiors 87, 95-109.

Buzzi, A., Foschini, L., 2000. Mesoscale Meteorological Features Associated with Heavy Precipitation in the Southern Alpine Region. Meteorology and Atmospheric Physics 72, 131-146.

Corona, C., Edouard, J.L., Guibal, F., Guiot J., Bernard, S., Thomas, A., Denelle,, N., 2011. Longterm summer (AD751-2008) temperature fluctuation in the French Alps based on tree-ring data. Boreas 40(2), 351-366

Couteaux, M., 1991. La limite supérieure de la forêt et sa valeur de seuil. Actes du colloque de Perpignan, 139-159.

Crowley, J.C., Zielinski, G., Vinther, B., Udisti, R., Kreutz, K., Cole-Dai, J., Castellano, E., 2008. Volcanism and the Little Ice Age. PAGES Newslettesr 16, 22-23.

Dapples, F., Lotter, A.F., van Leeuwen, J.F.N., van der Knapp, W.O., Dimitriadis, S., Oswald, D., 2002. Paleolimnological evidence for increased landslide activity due to forest clearing and land-use since 3600 cal BP in the western Swiss Alps. Journal of Paleolimnology 27, 239-248.

Debret, M, Chapron, E., Desmet, M., Rolland-Revel, M., Magand, O., Trentesaux, A., BoutRoumazeille, V., Nomade, J., Arnaud F., 2010. North western Alps Holocene paleohydrology recorded by flooding activity in Lake Le Bourget, France. Quaternary Science Reviews 29, 21852200. 
Delaygue, G., Bard, E., 2011. An Antarctic view of Beryllium-10 and solar activity for the past millennium. Climate Dynamics 36, 2201-2218.

Ducrocq, V., Nuissier, O., Ricard, D., Lebeaupin, C., Thouvenin, T., 2008. A numerical study of three catastrophic precipitating events over southern France. II: Mesoscale triggering and stationarity factors. Quarterly Journal of the Royal Meteorological Society 134, 131-145.

Enters, D., Arnaud, F., Poulenard, J., Giguet-Covex, C., Malet, E., Wilhelm, B., 2009. A Coupled Environmental Monitoring and Lake Sediment Study to Understand Factors Generating Torrential Floods in an Alpine Catchment (Giffre Valley, NW French Alps). Geophysical Research Abstracts 11, EGU2009-8837-1, EGU General Assembly, Vienna, Austria.

Faegri, K., Iversen, J., 1989. Textbook of Pollen Analysis. In. John Wiley \& Sons, New York, 328 pp.

Francus, P., Bradley, R.S., Abbott, M.B., Patridge, W, Keimig, F., 2002. Paleoclimate studies of minerogenic sediments using annually resolved textural parameters. Geophysical Research Letters 29(20), 1998.

Frei C., Schär, C., 1998. A precipitation climatology of the Alps from high-resolution rain-gauge observations. International Journal of Climatololgy 18, 873-900.

Gallet, Y., Genevey, A., Le Goff, M., 2002. Three millennia of directional variation of the Earth's magnetic field in western Europe as revealed by archeological artefacts. Physics of the Earth and Planetary Interiors 131, 81-89.

Gaume, E., Bain, V., Bernardara, P., Newinger, O., Barbuc, M., Bateman, A., Blaškovicová, L., Blöschl, G., Borga, M., Dumitrescu, A., Daliakopoulos, I., Garcia, J., Irimescu, A., Kohnova, S., 
Koutroulis, A., Marchi, L., Matreata, S., Medina, V., Preciso, E., Sempere-Torres, D., Stancalie, G., Szolgay, J., Tsanis, I., Velasco, D., Viglione, A., 2009. A compilation of data on European flash floods. Journal of Hydrology 367, 70-78.

Giguet-Covex, C., Arnaud, F., Poulenard, J., Disnar, J.R., Delhon, C., Francus, P., David, F., Enters, D., Rey, P.J., Delannoy, J.J., 2011. Changes in erosion patterns during the Holocene in a currently treeless subalpine catchment inferred and from lake sediment geochemistry (Lake Anterne, $2063 \mathrm{~m}$ a.s.1., NW French Alps): The role of climate human activities. The Holocene 21(4), 651-665.

Giguet-Covex, C., Arnaud, F., Enters, D., Poulenard, J., Millet, L., Francus, P., David, F., Rey, P.J., Wilhelm, B., Delannoy, J.J., 2012. Frequency and intensity of high-altitude floods over the last $3.5 \mathrm{ka}$ in NW European Alps, Quaternary Research 77(1), 12-22.

Gilbert, R., Crookshanks, S., Hodder, K.R., Spagnol, J., Stull, R.B., 2006. The record of an extreme flood in the sediments of montane Lillooet Lake, British Columbia: implications for paleoenvironmental assessment. Journal of Paleolimnology 35, 737-745.

Giorgi, F. Lionello, P., 2008. Climate change projections for the Mediterranean region. Global and Planetary Change 63, 90-104.

Giraudi, C., 2005. Late-Holocene alluvial events in the Central Apennines, Italy. The Holocene 15, $768-773$.

Goldberg, E.D., 1963. Geochronology with lead-210. In: Radioactive Dating, 121-131 pp. IAEA, Vienna, Austria.

Guiot J, Corona C, ESCARSEL members, 2010. Growing Season Temperatures in Europe and Climate Forcings Over the Past 1400 Years. PLoS ONE 5(4), e9972. doi:10.1371/journal.pone.0009972 
Haeberli, W., 1975. Untersuchungen zur Verbreitung von Parmafrost zwischen Flüelapass und Piz Grialetsch (Graubünden). Mitteilung der Versuchsanstalt für Wasserbau, Hydrologie und Glaziologie an der Eidgenössischen Technischen Hochschule Zürich 17, 221 p.

Hamilton, E.L., 1972. Compressional-wave attenuation in marine sediments. Geophysics 37, 620-646.

Hurrel, J.W., 1995. Decadal trends in the North Atlantic Oscillation: Regional temperature and precipitations. Science 269(5224), 676-679.

IPCC, Kostaschuck, R.A., MacDonald, G.M. (Intergovernmental Panel on Climate Change), 2007. Climate change 2007-the physical science basis. Cambridge University Press, Cambridge.

Irmler, R., Daut, G., Mäusbacher R., 2006. A debris flow calendar derived from sediments of lake Lago di Braies (N. Italy). Geomorphology 77, 69-78.

Jakob, M., Bovis, M., Oden, M., 2005. The significance of channel recharge rates for estimating debris-flow magnitude and frequency. Earth Surface, Processes and Landforms 30, 755-766.

Jansa, A., Genoves, A., Garcia-Moya, J.A., 2000. Western Mediterranean cyclones and heavy rain. Part 1: Numerical experiment concerning the Piedmont flood case. Meteorological Applications 7, $323-333$.

Juggins, S., 2007. C2 Version 1.5 User guide. Software for ecological and palaeoecological data analysis and visualisation.Newcastle University, Newcastle upon Tyne, UK. 73 pp. 
Kieffer-Weisse, A., 1998. Etude des précipitations exceptionnelles de pas de temps court en relief accidenté (Alpes Françaises), Méthode de cartographie des précipitations extrêmes. Thèse de doctorat, Institut National de Polytechnique, Grenoble. 309pp.

Kieffer-Weisse, A., Bois, P., 2001. Estimation de paramètres statistiques des précipitations extrêmes dans les Alpes françaises. La Houille Blanche 1, 62-70.

Kirov, B., Georgieva, K., 2002. Long Term Variations and Interrelations of ENSO, NAO and Solar Activity. Physics and Chemistry of the Earth 27, 441-448.

Lafargue, E., Marquis, F., Pillot, D., 1998. Rock-Eval 6 applications in Hydrocarbon exploration, poduction, and soil contamination studies. Revue de l'institut français du pétrole 53: 422-437.

Lanci, L., Hirt, A.M., Lotter, A.F., Sturm, M., 2001. A record of Holocene climate in the mineral magnetic record of Alpine lakes: Sägistalsee and Hinterburgsee. Earth and Planetary Science Letters $188,29-44$.

Luterbacher, J., Xoplaki, E., Dietrich, D., Jones, P.D., Davies, T.D., Portis, D., Gonzalez-Rouco, J.F., von Storch, H., Gyalistras, D., Casty, C., and Wanner, H., 2002. Extending North Atlantic Oscillation Reconstructions Back to 1500. Atmospheric Science Letters, 2, 114-124.

Magny, M., Bégeot, C., Guiot, J., Peyron, O., 2003. Contrasting patterns of hydrological changes in Europe in response to Holocene climate cooling phases. Quaternary Science Reviews 22, 1589-1596.

Magny, M., Peyron, O., Gauthier, E., Vannière, B., Millet, L., Vermot-Desroches, V., 2011.

Quantitative estimates of temperature and precipitation changes over the last millennium from pollen and lake-level data at Lake Joux, Swiss Jura Mountains. Quaternary Research 75, 45-54. 
Merz, R., Blöschl, G., 2003. A process typology of regional floods Water Resources Research 39(12), 1340

Miramont, C., Jorda, M., Pichard, G., 1998. Évolution historique de la morphogenèse et de la dynamique fluviale d'une rivière méditerranéenne : l'exemple de la moyenne Durance (France du sudest). Géographie physique et Quaternaire 52(3), 381-392.

Molinaroli, E., Guerzoni, S., De Falco, G., Sarretta, A., Cucco, A., Como, S., 2009. Relationships between hydrodynamic parameters and grain size in two contrasting transitional environments: The lagoons of Venice and Cabras, Italy. Sedimentary Geology 219, 196-207.

Morellón, M., Valero-Garcés, B., Vegas-Vilarrúbia, T., González-Sampériz, P., Romero, Ó., DelgadoHuertas, A., Mata, P., Moreno, A., Rico, M., Corella, J.P., 2009. Lateglacial and Holocene palaeohydrology in the western Mediterranean region: the Lake Estanya record (NE Spain). Quaternary Science Reviews 28, 2582-2599.

Morellón, M., Valero-Garcés, B.L., González-Sampériz, P., Vegas-Vilarrúbia, T., Rubio, E., Rieradevall, M., Delgado-Huertas, A., Mata, P., Romero, O., Engstrom, D.R., López-Vicente, E., Navas, A., Soto, J., 2011. Climate changes and human activities recorded in the sediments of Lake Estanya (NE Spain) during the Medieval Warm Period and Little Ice Age. Journal of Paleolimnology $46,423-452$.

Moreno, A., Valero-Garcés, B., Gonzales-Sampériz, P., Rico, M., 2008. Flood response to rainfall variability during the last 2000 years inferred from the Taravilla Lake record (Central Iberian Range, Spain). Journal of Paleolimnology 40, 943-961. 
Mulder, T., Migeon, S., Savoye, B., Faugères, J.C., 2001. Inversely graded turibidite sequences in the deep Mediterranean: a record of deposits from flood-generated turbidity currents? Géo-Marine Letters $21,86-93$

Nesje, A., Olaf Dahl, S., Matthews, J.A., Berrisdorf, M.S., 2001. A 4500 years of river floods obtained from a sediment core in Lake Atnsjoen, eastern Norway. Journal of Paleolimnology 25, 329_ 342.

Parris, A.S., Bierman, P.R., Noren, A.J., Prins, M.A., Lini, A., 2010. Holocene paleostorms identified by particle size signatures in lake sediments from the northeastern United States. Journal of Paleolimnology 43(1), 29-49.

Passega, R., 1964. Grain-size representation by CM patterns as a geological tool. Journal of Sedimentary Petrology 34(4), 830-847.

Pauling, A., Luterbacher, J., Casty, C., Wanner, H., 2006. Five hundred years of gridded highresolution precipitation reconstructions over Europe and the connection to large-scale circulation. Climate Dynamics 26, 387-405.

Peng, Y., Shen, C., Wang, W.C., Xu, Y., 2010. Response of Summer Precipitation over Eastern China to Large Volcanic Eruptions. Journal of Climate 23, 818-824.

Raible, C.C., Yoshimori, M.,Stocker, T.F., Casty, C., 2007. Extreme midlatitude cyclones and their implications for precipitation and wind speed extremes in simulations of the Maunder Minimum versus present day conditions. Climate Dynamics 28, 409-423.

Reimer, P.J., Baillie, M.G.L., Bard, E., Bayliss, A., Beck, J.W., Blackwell, P.G., 2009. IntCal09 and Marine09 radiocarbon age calibration curves, 0-50,000 years cal BP. Radiocarbon 51, 1111-1150. 
Remaître, A., 2006. Morphologie et dynamique des laves torrentielles : Applications aux torrents des Terres Noires du bassin de Barcelonnette (Alpes du Sud). Thèse de doctorant, Université De CaenBasse Normandie. 374pp.

Reyss, J.L., Schimdt, S., Legeleux F., Bonte, P., 1995. Large low background well type detectors for measurements of environmental radioactivity. Nuclear Instruments and Methods in Physics Research $357,391-397$.

Sanchez-Gomez E., Terray L., Joly B., 2008. Intra-seasonal atmospheric variability and extreme precipitation events in the European-Mediterranean region. Geophysical Research Letters 35, L15708.

Schiefer, E., Gilbert, R., Hassan, M.A., 2011. A lake sediment-based proxy of floods in the Rocky Mountain Front Ranges, Canada. Journal of Paleolimnology 45, 137-149

Sivan, O., Miramont, C., Pichard, G., Prosper-Laget, V., 2009. Les conditions climatiques de la torrentialité au cours du Petit Age Glaciaire de Provence. Archéologie du Midi Médiéval 26, 157-168.

Solomon, S., Qin, D.,Manning, M.,Marquis,M., Averyt, K., Tignor, M.M.B., Miller,H., Chen, Z. (Eds.), 2007. Climate Change 2007: The Physical Science Basis. Contribution of Working Group I to the Fourth Assessment Report of the Intergovernmental Panel on Climate Change. Cambridge University Press, Cambridge.

Stoffel, M., Lièvre I., Conus D., Grichting M. A., Raetzo H., Gärtner H. W., Monbaron M., 2005. 400 Years of Debris-Flow Activity and Triggering Weather Conditions: Ritigraben, Valais, Switzerland. Arctic, Antarctic, and Alpine Research 37(3), 387-395.

Stoffel, M., Bollschweiler, M., Beniston, M., 2011. Rainfall characteristics for periglacial debris flows in the Swiss Alps: past incidences-potential future evolutions. Climatic Change 105, 263-280. 
Sturm, M., Matter, A., 1978. Turbidites and varves in Lake Brienz (Switzerland): deposition of clastic detritus by density currents. Special Publications of International Association of Sedimentologists $2,147-168$.

Tachikawa, K., Cartapanis, O., Vidal, L., Beaufort, L., Barlyaeva, T., and Bard, E., 2011. The precession phase of hydrological variability in the Western Pacific Warm Pool during the past $400 \mathrm{ka}$. Quaternary Science Review 30, 3716-3727

Trigo, I.F., Davies, T.D., 2000. Decline in Mediterranean rainfall caused by weakening of Mediterranean cyclones. Geophysical Research letters 27 (18), 2913-2916.

Vacquero, J.M., 2004. Solar signal in the number of floods recorded for the Tagus River basin over the last millennium. Climatic Change 66, 23-26.

Wilhelm, B., Arnaud, F., Enters, D., Allignol, F., Legaz, A., Magand, O., Revillon, S., Giguet-Covex, C., Malet, E., in press. Does global warming favour the occurrence of extreme floods in European Alps? First evidences from a NW Alps proglacial lake sediment record, Climatic Change. DOI: 10.1007/s10584-011-0376-2

Zijderveld, J.D.A., 1967. AC demagnetization of rock: analysis of results. In: Collinson, D.W., Creer, K.M., Runcorn, S.K. (Eds.), Methods in Paleomagnetism. Elsevier, Amsterdam, pp. 254-286.

\section{Figures}

Fig. 1. Location of Lake Allos and other sites referred to in the article (upper left panel). Hydrological, geological and geomorphological characteristics of the Lake Allos catchment area (upper right panel). Bathymetric map of Lake Allos, A-B seismic profile and location of the three cores studied (lower panels) 
Fig.2 Photograph of Lake Allos and its catchment area, taken from the east in July 2011

Fig. 3. Stratigraphic correlations of the cores studied, based on sedimentary facies, relative sulfur and calcium contents, and total organic carbon content (TOC). Relative sulfur and calcium contents were measured using core scanner analyses and are expressed in $10^{3}$ peak area. The size of TOC points correspond to the sample thickness. ${ }^{14} \mathrm{C}$ samples are indicated by red stars.

Fig. 4. Grain size features and $\mathrm{Q}_{90 \max }$-thickness relationship for the graded deposits in core ALO09P13

Fig. 5. (A) ${ }^{226} \mathrm{Ra},{ }^{210} \mathrm{~Pb},{ }^{137} \mathrm{Cs}$ and ${ }^{241} \mathrm{Am}$ profiles for core ALO09P12. (B) Application of a CFCS model to the synthetic sedimentary profile of ${ }^{210} \mathrm{~Pb}$ in excess (without thick graded beds considered as instantaneous deposits). (C) Resulting age-depth relationship with $1 \sigma$ uncertainties and indications of historic flood dates, possibly associated to the thick graded deposits.

Fig. 6. Correlative magnetic features (D-1 to D-4) between the measured and reconstructed variations of the geomagnetic declination (Bucur, 1994; Alexandrescu et al., 1997; Gallet et al., 2002) and the ChRM declination profile of core ALO09P12 (A). Age-depth model for cores ALO09P12 produced with "clam” R-code package, combining historic ${ }^{137} \mathrm{Cs}$ peaks, ${ }^{210} \mathrm{~Pb}$ resulted sedimentation rate, ${ }^{14} \mathrm{C}$ ages and magnetic declination features (B).

Fig. 7. Pollen diagram for core ALO09P11. Only selected palynological taxa and groups are shown (see text for explanation). Horizontal solid lines represent samples analyzed. Dashed lines show exaggeration curves used to magnify occurrences of rare pollen taxa (percentages are multiplied by 5). Indicated ages and historical periods (right panel) derived from the ALO09P12 age-depth model and the core-to-core correlation of organic-rich layers. 
Fig. 8. Comparison of (B) reconstructed Allos flood frequency (31 yr running average) and intensity (thickness of flood deposits) with (A) periods of high flood frequency over a large study area and the reconstructions of (C) relative variations in the level of Lake Estanya (Spanish Pyrennees), (D) treering-based summer temperature for the southern Alps and Europe, (E) autumnal NAO index, (F) solar activity and (G) major volcanic eruptions in northern hemisphere. References for the flood records are: (1) Remaître, 2006, (2) Sivan et al., 2009, (3) Blanchemanche, 2009, (4) Barrera et al., 2006, (5) Vallve and Martin-Vide, 1998 based on historical records and (6) Moreno et al., 2008 based on a lake sediment sequence.

Fig. 9. Dominating situations over the last four centuries during which extreme events affected the dotted area: (1) Allos Lake, (2) Vidourle and Herault Rivers, (3) Rivers of Barcelona county, (4) Rivers of the Spanish Mediterranean coast and (5) Taravilla Lake. The blue arrow and the dashed lines indicate the main moisture flux and its approximate limits, determined from meteorological reanalysis of recent catastrophic "Cévenole" and "Southern Alps"-type events (from Boudevillain et al., 2009).

Table. 1. Radiocarbon dates for core ALO09P12 and ALO09P13. We calculated the synthetic sedimentary depth by removing the graded beds, which were considered to be instantaneous deposits. See text for explanation, nature of samples and calibration procedures.

\section{SUPPLEMENTARY MATERIAL}

Table. 2 List of historical flood events on the Chadoulin River, which runs through the village of Allos (based on the National Forestry Service's free-of-access database, see text for details). Reference numbers enable these events to be easily found in the database. N means No, $\mathrm{Y}$ means Yes and $\mathrm{U}$, Uncertain. 


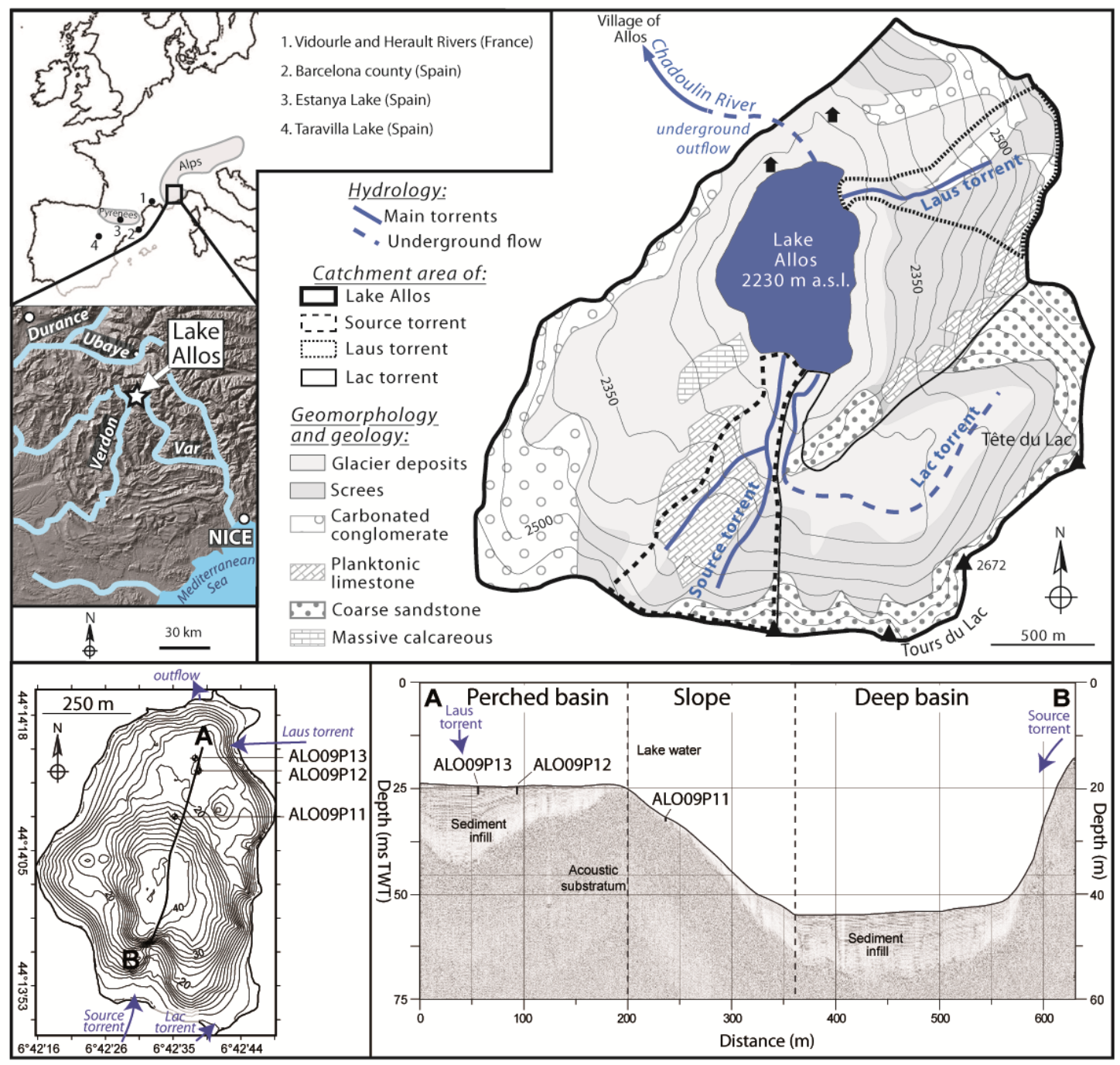




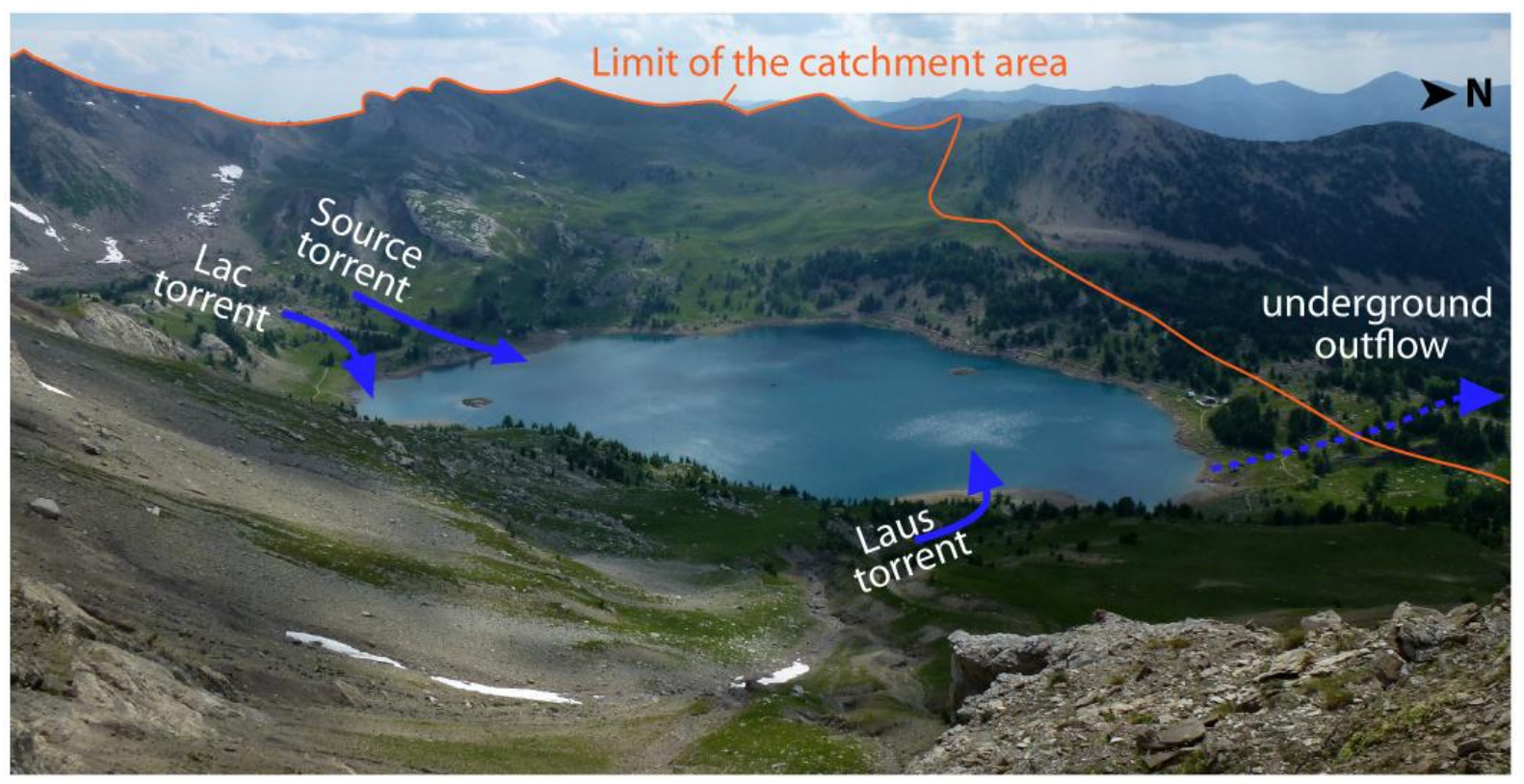




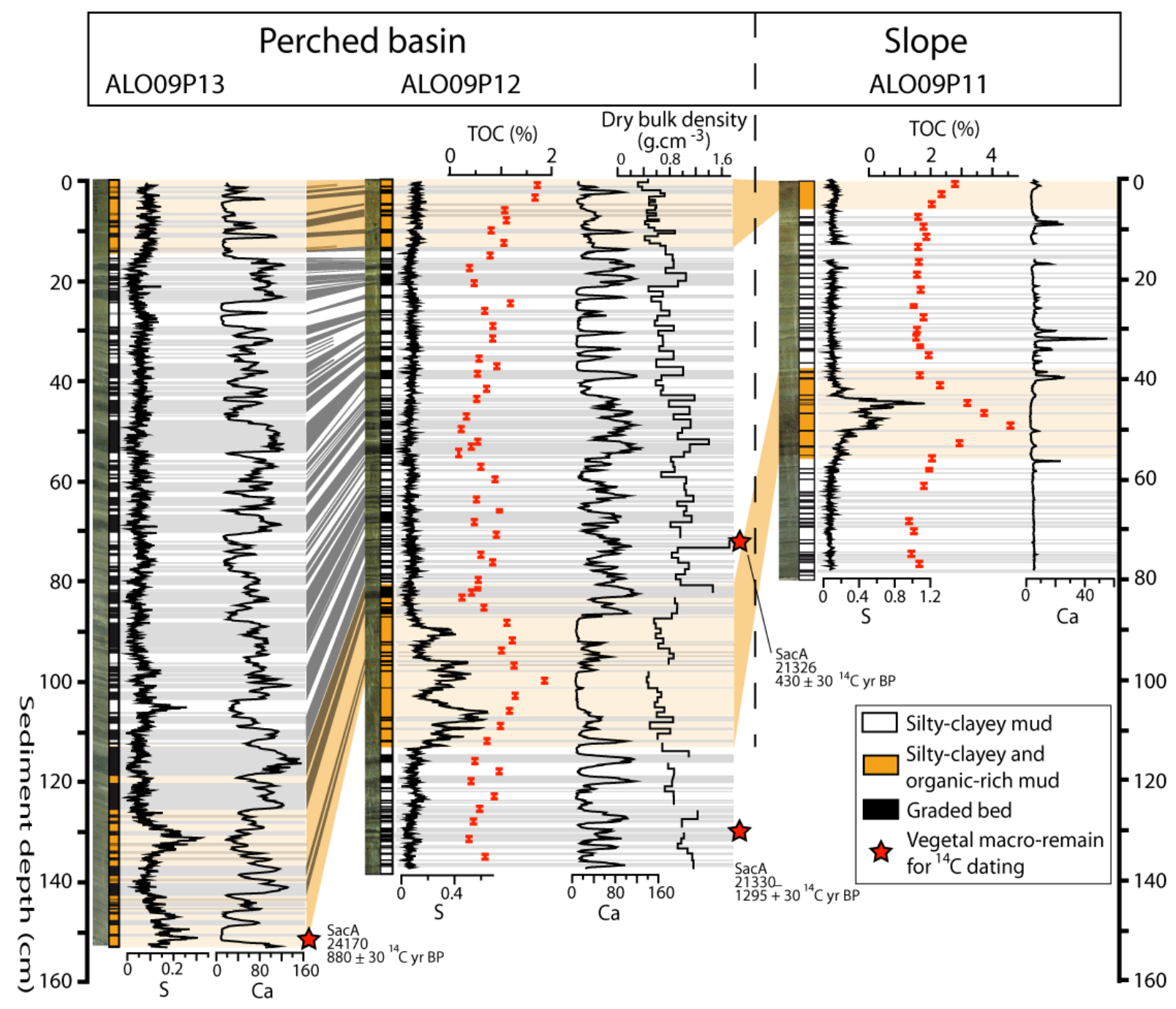




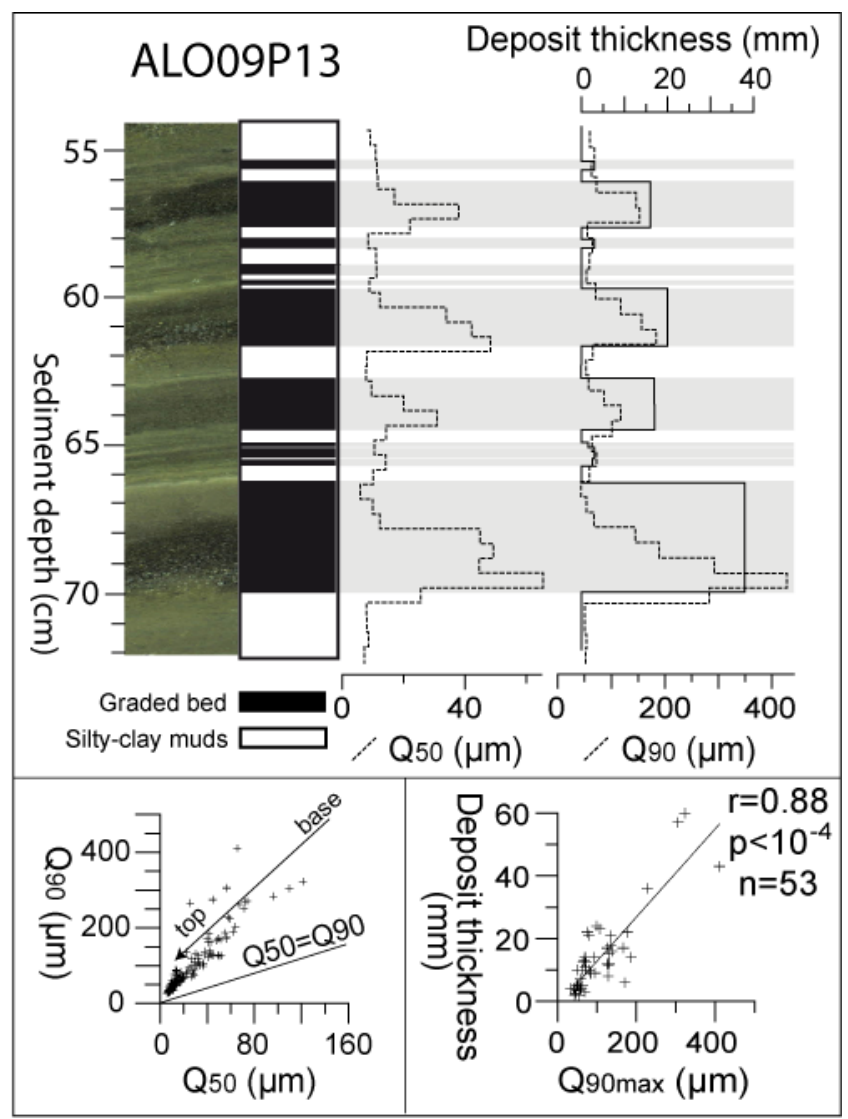




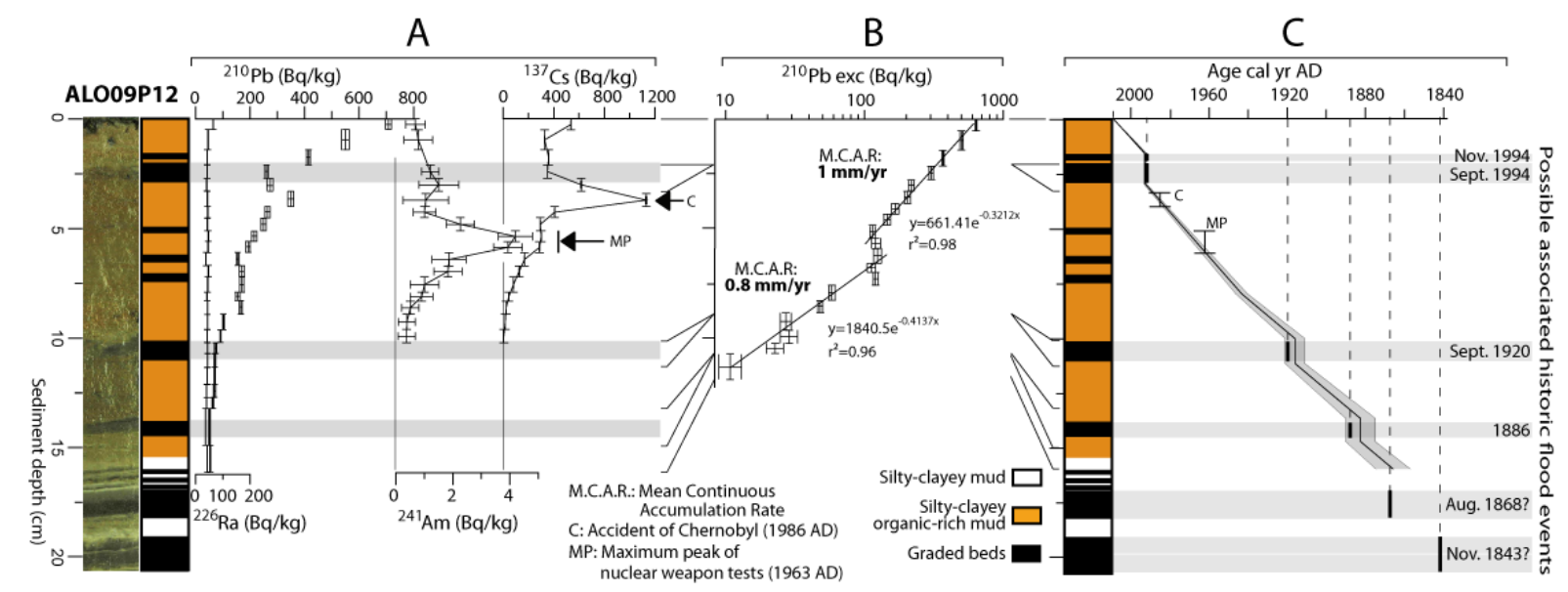




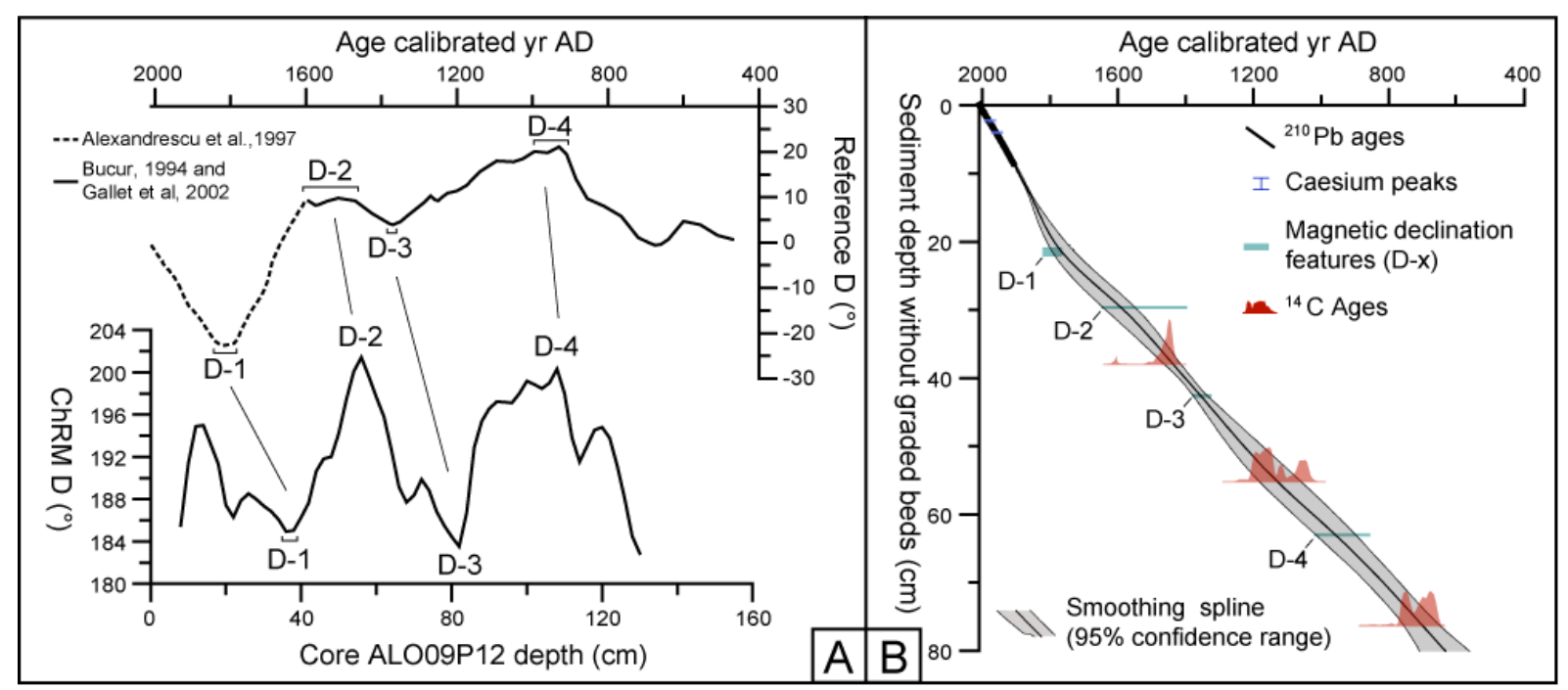




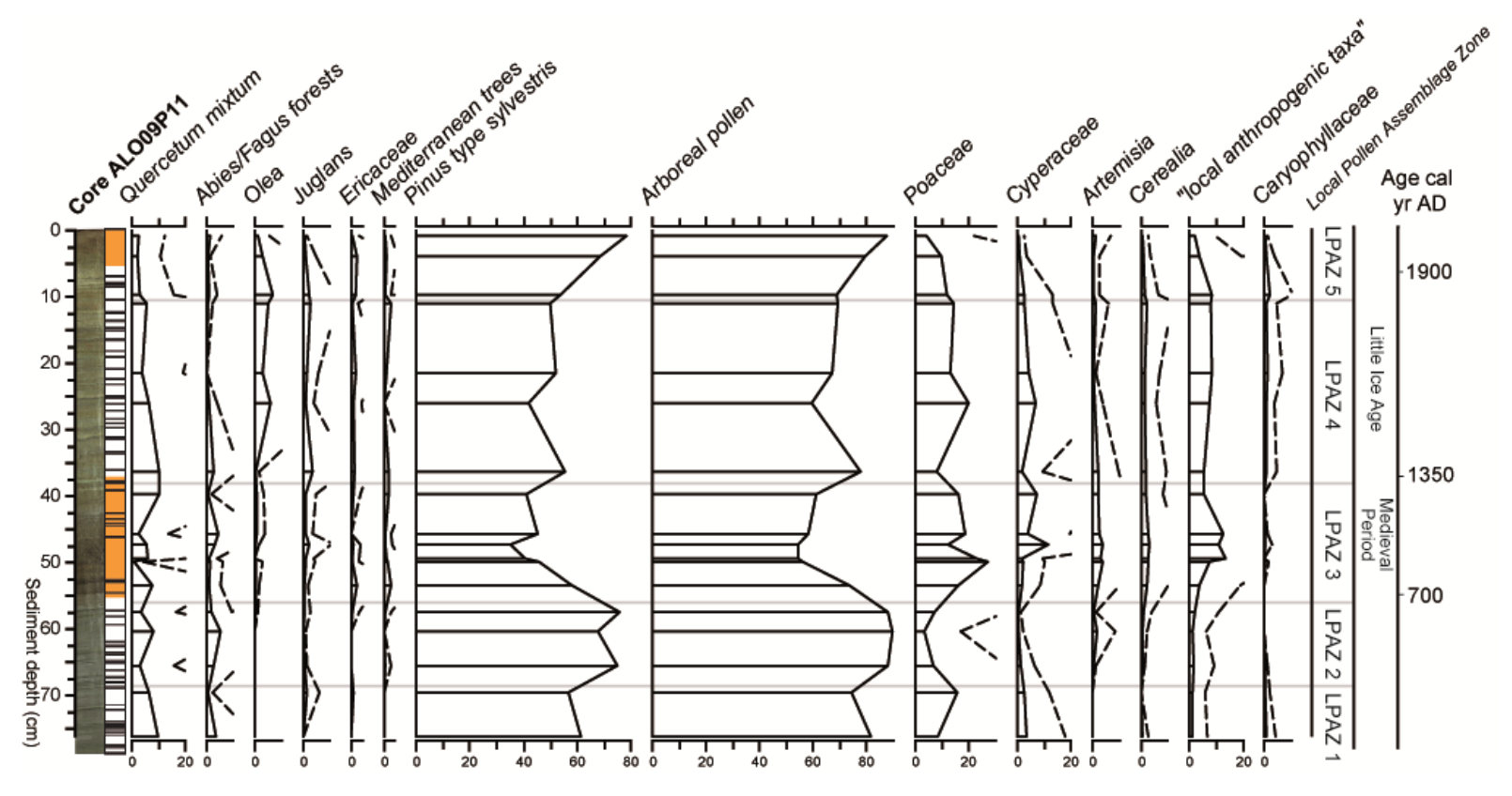




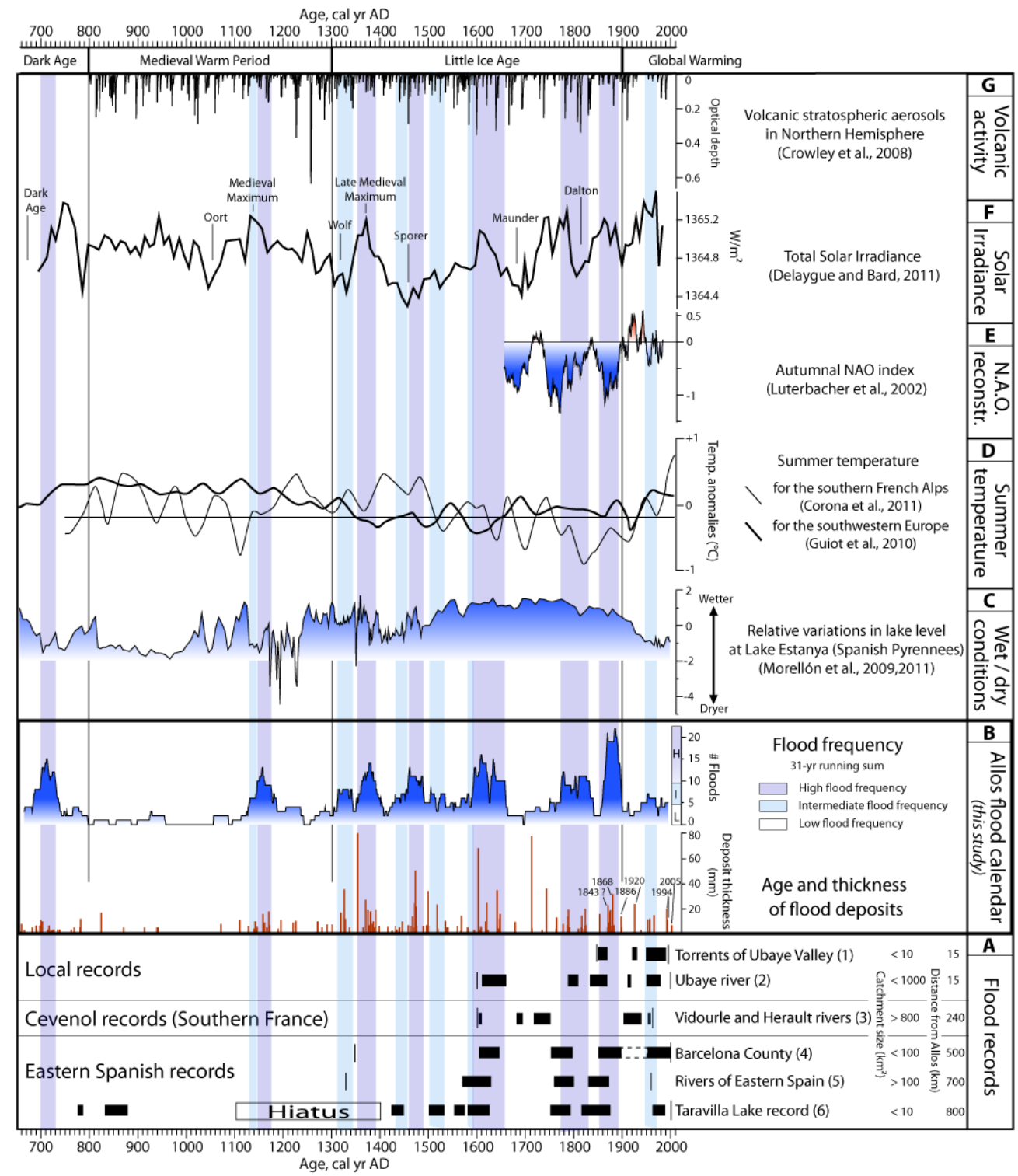




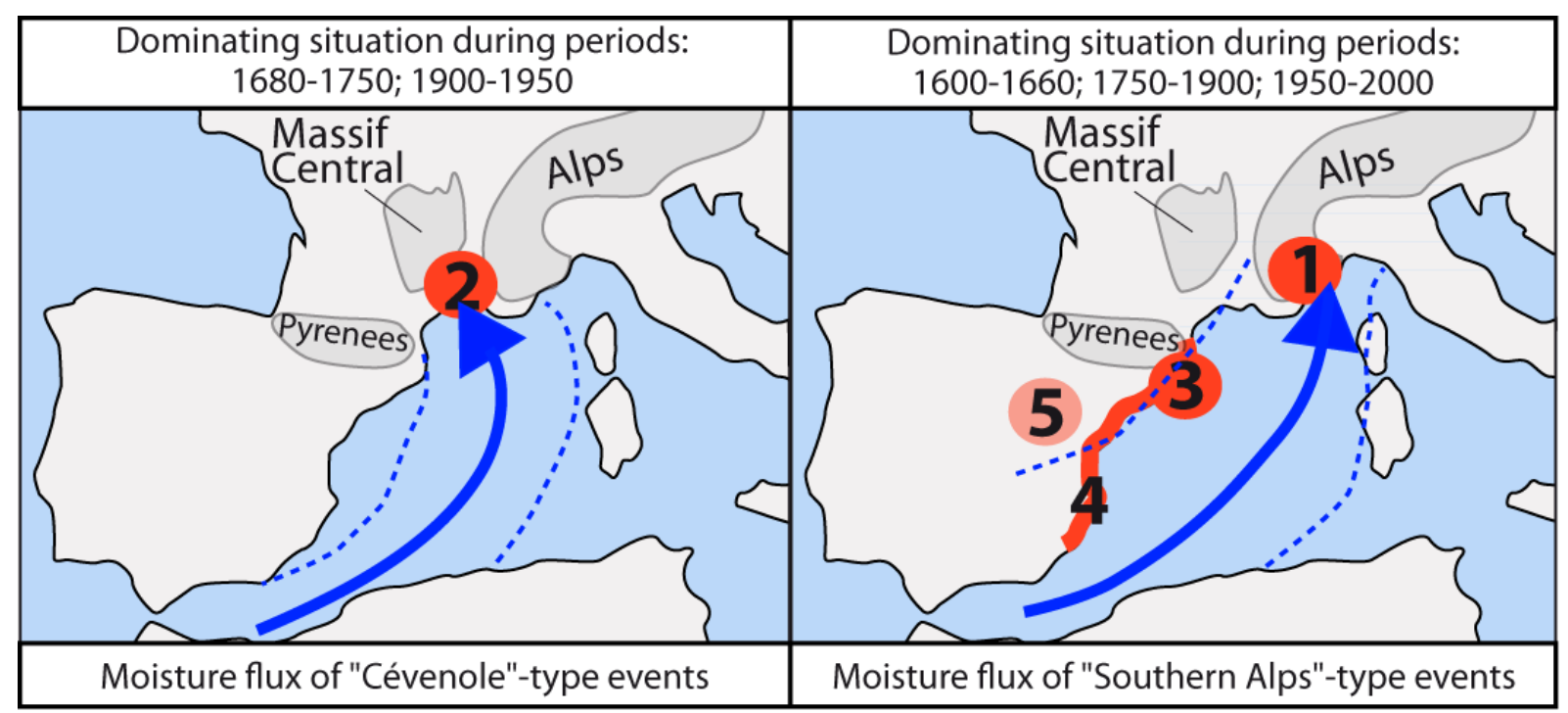




\begin{tabular}{lccccc} 
Lab. Code & $\begin{array}{c}\text { Core depth } \\
(\mathrm{cm})\end{array}$ & $\begin{array}{c}\text { Synthetic sedimentary depth } \\
\text { for core ALO09P12 }(\mathrm{cm})\end{array}$ & $\begin{array}{c}\text { Radiocarbon age } \\
{ }^{14} \mathrm{C} \text { yr BP }\end{array}$ & $\begin{array}{c}\text { Calibrated yr BP } \\
(2 \sigma)\end{array}$ & $\begin{array}{c}\text { Calibrated yr AD } \\
(2 \sigma)\end{array}$ \\
\hline SacA 21326 & $71-73(\mathrm{P} 12)$ & 37.8 & $430+/-30$ & $335-529$ & $1421-1615$ \\
SaCA 24170 & $151-152(\mathrm{P} 13)$ & 55.4 & $880+1-30$ & $730-907$ & $1043-1220$ \\
SacA 21330 & $130-132(\mathrm{P} 12)$ & 76.3 & $1295+1-30$ & $1177-1287$ & $663-773$
\end{tabular}

